\title{
Applying Communication Theory to Structure and Evaluate the Social Media Platforms in Academia
}

\author{
Qusay Al-Maatouk ${ }^{1,2}$, Mohd Shahizan Othman ${ }^{2}$, Alhuseen Omar Alsayed ${ }^{3}$, Ali Mugahed Al-Rahmi ${ }^{4}$, \\ Hassan Abuhassna ${ }^{5}$, Waleed Mugahed Al-Rahmi ${ }^{6}$ \\ ${ }^{1}$ School of Technology, Asia Pacific University of Innovation and Technology, Bukit Jalil, 57000, Kuala Lumpur, Malaysia \\ qusay@staffemail.apu.edu.my \\ ${ }^{2}$ Faculty of Engineering, School of Computing, UniversitiTeknologi Malaysia, Johor Bahru, 81310, Johor, Malaysia. shahizan@utm.my \\ ${ }^{3}$ Deanship of Scientific Research, King Abdulaziz University, Jeddah, Saudi Arabia. aoalsayd@kau.edu.sa \\ ${ }^{4}$ Faculty of Technology Management and Business, Universiti Tun Hussein Onn Malaysia, BatuPahat, 86400, Johor, Malaysiaemail \\ ali.alrahmi1@gmail.com \\ ${ }^{5}$ Faculty of Social Sciences \& Humanities, School of Education, UniversitiTeknologi Malaysia, 81310, UTM Skudai, Johor, Malaysia, \\ mahassan@utm.my \\ ${ }^{6}$ Faculty of Social Sciences \& Humanities, School of Education, UniversitiTeknologi Malaysia, 81310, UTM Skudai, Johor, Malaysia, \\ waleed.alrahmi@yahoo.com
}

\begin{abstract}
The aim of this research was to reduce the dissimilarities in the literature regarding the use of social media platforms (SMPs) for training and its impact on students' satisfaction and academic performance in higher education institutions. The main method of data collection for Communication Theory (CT) was a questionnaire survey. This research hypothesizes that CT applied to social media platforms for learning will affect online communication, motives to communicate, communication self-efficacy and attitude towards usethat in turn improve students' satisfaction and students' academic performance. The data collection questionnaire was conducted with 309 students familiar with social media platforms. Quantitative structural equation modeling was employed to analyze the results. A significant relationship was found between online communication, motives to communicate, communication self-efficacy and attitude towards usefeatures with TC for utilizing social media platforms for academic purposes that positively affected satisfaction and academic performance. Therefore, the study indicates that TC theory to use social media improve the collaborative learning of students and enable them to efficiently share knowledge, information, and discussions. We recommend that students utilize social media platforms in pursuit of their educational goals. Educators should also be persuaded to incorporate social media platforms into their classes at higher education institutions.
\end{abstract}

Key words: Communication Theory, Social Media, Structural Equation Modelling

\section{INTRODUCTION}

In spite of the upsurge of social media usage for educational purposes, inadequate research works have been carried out in exploring social media usage in Malaysian universities[1]. Equally,D Ryu and J Jeong [2]claimed that students find no association with the activities performed in online learning and communication. In general, studies have stressed on the exploitation of social media usage and the wellunderstanding of it for learners to enable the creation of learner-focused systems in education[3].According to IL Stats [4], 68.6\% of the Malaysian population have reliable access to Internet services, and $64 \%$ of this population are utilizing social media networks. The Malaysian population number who are on social media is increasing to the number of 13 million and growing 350,000 new users approximately in 2012 first six months [5]. Thus, this could demonstrate the crucial role of the social media in the daily routine of Malaysian people, however, it still needs to be further and more in-depth investigated to comprehend the importance of using social media by people [6]. For the practical contribution section, this study permits stakeholders in faculties, departments, and research management departments in universities, as well as the ministry of higher education, to have a comprehensive awareness of social media usage for communication and learning to affect students' academic performance and satisfaction by technology acceptance and interactivity. Consequently, learners will be encouraged to make use of social media for educational purposes. Furthermore, the study aims to develop an instrument and factors for academic organizations to measure and analyze the students' academic performance and satisfaction in terms of technology use.

\subsection{Educational use of social media}

As the features of social media platform were constructed solely for the purpose of enriching the way people communicate and interact socially, their application in education serves several advantages to pedagogy which can be beneficial toward educationenvironment benefiting both 
for students and the instructors [7]. Due to the values it brings to pedagogy, instructors in higher education are beginning to devote their resources including effort and time utilizing the tools to enrich and mediate student learning [8]. about higher education perspective, several scholars suggest the deployment of social media which simplifies social education inside classes [9-11], enhances active learning by inspiring both learners and instructors to interact among each other [12], then promotes the learning activities that are students-centered [13]. Through literature, major social media use that is frequently examined is continuous connectivity and its value it provides to the higher education institutions that improves student communication and learning [14], which presents the learning type that is based on learners demands [15]. Furthermore, learners can retrieve swift updates regarding the information of the course as well as the course content whereas can be attained easily using the continuous connectivity of social media [16]. Definitions of social media have changed continually with a potentially improved characteristic to meet user specifications and demands. On the other hand, social networks are primarily created to satisfy the various niche markets to assist particular consumer's requirements and interest. Social media sites have the capabilities and function of social media in order to make it simpler for its consumers to add friends, send mails, take part in groups, create personal profiles, content development, applications development, find out about different users [17]. The present internet, occasionally referred to as Web 2.0, permits for further Communication, modification and interaction, through the consumers [18] other than the previous type, that's used to be called web 1.0, which was less interactive and more inactive in its nature. They comprise of diverse and numerous items as mentioned by [19], for instance communication for learning through YouTube Blogs and Facebook.

\section{MODEL AND HYPOTHESES}

The theoretical model proposed in the present study is exploring all factors related to the TC theory such as (affect online communication, motives to communicate, communication self-efficacy and attitude towards use). These mentioned factors are found to be consequently influence the satisfaction and academic performance of students at institutes of higher education and are being discussed in this section accordingly See Figure.1.

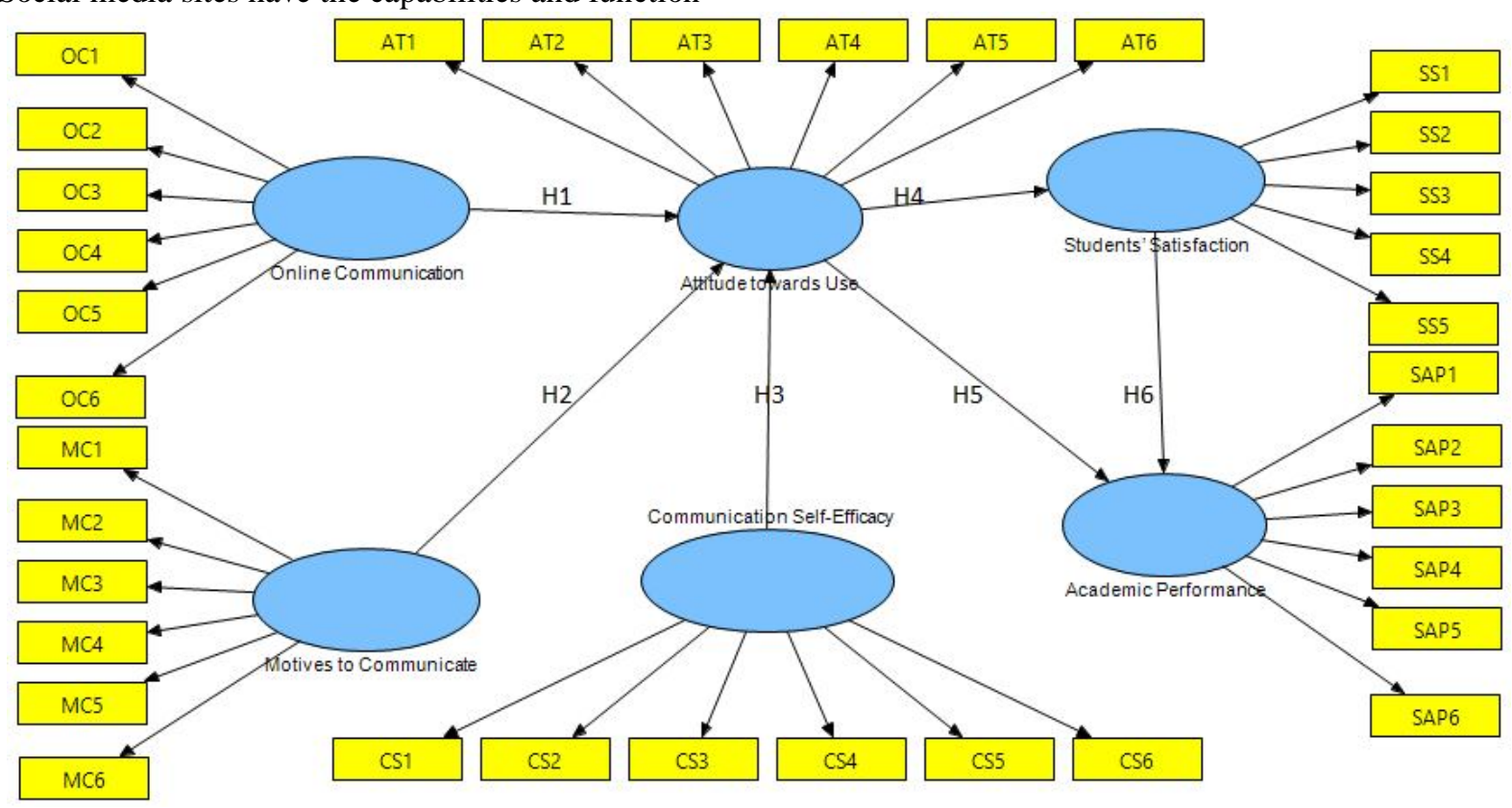

Figure 1: Research Model

\subsection{Online Communication for Learning}

Social media isn't merely utilized for informal social networking or else improving social capital [20] then also aimed at improving consumer relations [21], marketing and online engagement [22] and complaint resolution and problem handling [23] across a variety of various sectors from different people. Educational sector had similarly acceded to the social media trend and adopted it on a global basis. In Higher-education, social media could also be employed for sharing, generating content, collaboratively socializing and networking [24]. Social media could have been used towards educational information, provide education material, facilitate and updates, collaboration with communication. Facebook's social interaction features beneficial for students as well as educators by setting up an online tutorial group as well as improving communications among learner-learner along with instructor-learner [25] in addition to encouraging collaborative education through use Massive open online courses (MOOCs)[21]. Consciousness of the social media impact on courses is critical for instructors [26].The research does not mention the context complexities of specific education sectors then the importance of communications that may take a role in everyone, instead it offers short summary regarding few 
communication values among 'typical' teaching schemes then mentions few of the possible pressures included [27]. One possible approach to solve restricted connections inside classroom is by technology [28].Thus, AM Ledbetter and AN Finn [29] claim, it is possible that university learners also want to anticipate its teachers towards accept, as well as perhaps at the same time encouraging their students to utilize the technology inside classroom. Still, research however offers a partial knowledge on how technology influences involvement with repeated examples whereas a person could employ technology (e.g., [30] and case studies (e.g., [31], although not the connections among participation and technology use. Even Though earlier studies of technology in classrooms were revealing, they frequently stop short of theories on whereas contribution is improved. Subsequently, in this research they provide a broader model of how ICTs could improve participation in classroom. Accordingly, they look to dual consistent assessments of classroom participation: learner motives to interact with his/her attitudes throughout online communication. Thus, learner motives to connect Theorizing the classroom interactions as group of unique social interactions, scholars claim it necessary to identify the reasons causing learners participating into interactions among their own teachers [32]. Motives could be described as learners' own motivations for communicating with teachers [33]. Thus, five main motives about learners to interact were recognized: sycophantic, excuse making, functional, relational, and, most important to the current research, participating justifications. Thus, Participating interactions motives, learning motives through communications methods [34], push learners to make a contribution to classroom discussion by comments and other interaction forms. In view of the above discussion, the researchers propose the following hypothesis:

H1: The relationship between OC and AT.

\subsection{Motivate to Communication in Learning}

Theorizing the communication class like a singular position of human relations, scholars claim it is important to recognize the motivations after learners to develop relations among teachers [35]. Motivations could described as learners have their justifications for communicating to teachers [36]. Attaining the attention of learners and compelling them is a major challenge in an online setting. $\mathrm{R}$ Chugh and $U$ Ruhi [37] have mentioned strategies to improve an online learning setting and motivate learners by Emphasizing critical points through the content, supporting the content with multimedia, offering crystal-clear guiding queries, employing both asynchronous and synchronous tools, and frequently interacting with learners . Expanding discussions over and above face-to-face interaction as well as on to Facebook calls for intrinsic and extrinsic measures to motivate learners by configuring tasks that encourage students to use their higher-order intellectual skills [38]. Extrinsic incentives like participation marks for how to use the Facebook for out-of-class discussion has a positive influence on academic achievement [39]. Teachers will have to be very more active in the early stages of Facebook activity formation to help guide the direction of online discussion by learners and answering their questions [40]. In order to enhance interaction with learners on Facebook and in real-life situations and to ease learning, the role of educators should concentrate on being an investigator, counsellor, participant, prompter, and organizer rather than a controller, assessor and corrector [41].R Chugh and U Ruhi [37] proposed that utilization of online tutor to selfdisclosure that use Facebook in an online administered language lesson encourages a shift in learners' motivation type - from extrinsic to intrinsic motivation. Intrinsic motivation has a tendency to yield the greatest positive outcomes in the educational process [42]. A Forkosh-Baruch and A Hershkovitz [43] also emphasized that the teacher self-disclosure using Facebook has resulted in the students showing excitement and improved interactions in contrast to a control group. In view of the above discussion, the researchers propose the following hypothesis:

$\mathrm{H} 2$ : The relationship between MC and AT.

\subsection{Communication Self-Efficacy}

Self-efficacy is a person's assessment of that person's own ability regarding some expected behavior[44]. Individual with elevated self-effectiveness may be more expected to execute a certain behavior since that person considers within their abilities to do that [45]. Share knowledge selfeffectiveness more accurately describes the belief an individual must being able to efficiently exchange information. To obtain this belief, an individual should be persuaded to possess real-world knowledge in value distribution then the necessary skills to deliver this information. Research regarding both off-line and online information sharing indicated that Share knowledge selfeffectiveness is a significant forecaster of knowledge sharing behavior, particularly within an online perspective [46, 47]. There's also circumstantial sign of which a deficiency of Share knowledge self-effectiveness can hinder the sharing of knowledge. For instance, [48] mention qualitative research that involves online communities and the conclusion that lack of time and inexperience with the topic, two are of the major reasons why people refrain from sharing knowledge. [49] mention similar outcomes from quantitative research on online knowledge sharing. In The Same Way, in an effort to find out why Wikipedia users don't have the intention to contribute towards online encyclopaedia, [50] determined that the primary reason for non-contribution is that one considers to lack the necessary information to make a contribution. Building on these findings they could therefore come to the conclusion that whenever people believe they are not acquainted with a topic, or have not enough significant knowledge to share, they may choose not to share this knowledge.In view of the above discussion, the researchers propose the following hypothesis:

H3: The relationship between CS and AT.

\subsection{Attitude towards use}

According to the definition, attitudes are favourable or unfavourable, raising the question of the coherence. YK Dwivedi, NP Rana, A Jeyaraj, M Clement and MD Williams [51] suggested responses may be deemed to be in line when the person's assessments fall at either the positive or the 
negative end of the dimension. R Lowe and P Norman [52] claimed that if one has positive emotions and thoughts towards some object, an individual's behavioral attitude towards it would also tend to reflect the fact that approval; in other terms, overt actions are usually products of implicit assessments. On that ground, one would assume instructors' positive perceptions and feelings about learners' media usage in the class to be reflected in favourable actions.Although motivation is a potent indicator of the reason that learners interact in the classroom, it doesn't show how learners feel about that interaction. JB Becton, HJ Walker, P Schwager and JB Gilstrap [53] identified motivation as being the effort to maintain and initiate an engagement in education. The attitudes significance is particularly relevant to online communication; in such a way, Arthurhypothesize here about motivations besides attitudes. As [54] says, online attitudes are likely to have variance experiences and consequences, thus affecting interpersonal interaction patterns in an exceptional manner. On the other hand, [55] description of attitudes as a comparatively persistent association of attitudes across a situation or an object influencing an individual to react in some special manner in order to create a degree for considerate communicating online attitudes. In Particular, [54] theorized online interaction attitudes as the cluster of affective and cognitive guidance can inhibit or enhance a person's propensity to communicate online. Despite The Fact That other people have proposed attitudes models which using online technology e.g., [56, 57], these patterns fail to explain the motivations communicative elements. As more classes continue to add aspects of social media $[58,59]$ and collegiate teaching becomes more polymerizate [30], it's essential to consider these attitudes that could form the ways in which students cooperate in the classroom. In view of the above discussion, the researchers propose the following hypotheses:

H4: The relationship between AT and SS.

H5: The relationship between AT and AP.

\subsection{Students' Satisfaction}

Certain scholars established the potential and chance of social media to stimulate education by enabling information sharing and communication, encouraging student, engagement collaboration, and supporting [60-63]. As stated by R Kern, P Ware and M Warschauer [64], Facebook can generate a more comfortable classroom atmosphere, connect students and instructors, develop learners' and motivational level, and encourage cooperative models of education. Earlier results have proved that collaborative education positively influences satisfaction of student's $[65,66]$. NM Labib, AE Sabry, RH Mostafa and EW Morcos [67] examine the factors of social media employing in collaborative education amongst postgraduate and undergraduate learners through examining the intrinsic and extrinsic motivation role, intentions and attitude. Significance of the research is examining using social media impacts in collaborative education on students, both postgraduate or undergraduate, from various facets like decision making, collaboration, socialization, interaction, performance, and student satisfaction. Depending on the outcome, collaborative education substantially impacts behavioural intention in the of use social media then influences learning and teaching of students [68, 69]. In view of the above discussion, the researchers propose the following hypothesis:

H6: The relationship between SS and AP.

\subsection{Students' Academic Performance}

According to N Saha and AC Karpinski [70] social media through fields of research affects Students' academic performance and satisfaction of their users; In reality, social group formed on the Facebook was found to make it easier for learner development. Nevertheless, there are several exceptional instances where results show positive correlation between Twitter and Facebook [23, 69] and that incorporation could enhance education [71]. Investigation by D Laha and R Pal [72], the researcher noted that learners consume additional time utilizing social media for a different purpose besides learning usage, therefore influencing their learners academic performance. Study has been further elaborated by AC Karpinski, JV D'Agostino, A-EK Williams, SA Highland and JA Mellott [73] by which the scholars declared that social media consumers had lower ranking than learners who would never participate in social communications. Nevertheless, there are common advantages correlated with social media users. [74] clarified that social media are sources of communication, collaboration and interactivity, amongst research lecturers and students in their own faculties. Additionally, S Cooke [75] suggested that social media did not affect academic performance of the students'. Furthermore, a research by [76], tried to examine the connection amongst students' academic performance and Facebook. Conclusions showed that that there is considerable negative association among students' academic performance and Facebook use. People Surveyed described devoting less times per week studying on average versus nonusers. Majority said that they used their Facebook accounts at least once daily, this is consistent with the results of [77].

\section{RESEARCH METHODOLOGY}

The selected research model included undergraduate and postgraduate social media users to examine TC theory in order to measure students' satisfaction and students' academic performance. The data were obtained using 5-point Likert scales, including demographic elements of the TC variables. The questionnaire that was physically circulated asked all respondents to provide feedback on the use of social media for TC and their opinions about its influence on students' satisfaction and students' academic performance. The data were collected randomly from Universiti Utara Malaysia (UUM) and International Islamic University Malaysia (IIUM) and analyzed using IBM SPSS and Structural Equation Modeling (SEM-Smart PLS). These are considered the most important statistical methods in our study and consisted of two stages. In the first, the validity of measures, measure convergence validity, and discriminant validity of the measure were conducted, and the structural model examination was performed in the second. This 
method was suggested by Hair et al. [78]. The sample size representative of the farmers in this study is 309 undergraduate and postgraduate students. It is determine based on the Krejcie and Morgan's sample size calculation which same as using the Krejcie and Morgan's sample size determination, which expressed as below equation [79]. The Krejcie and Morgan's sample size calculation was based on $p=0.05$ where the probability of committing type I error is less than $5 \%$ or $\mathrm{p}<0.05 . \mathrm{S}=\mathrm{X}^{2} \mathrm{NP}(1-\mathrm{P}) \pm \mathrm{d}^{2}(\mathrm{~N}-1)+\mathrm{X}^{2} \mathrm{P}(1-$ $\mathrm{P})$. whereby $(\mathrm{S})$ is the required sample size, $(\mathrm{N})$ the population size, $(\mathrm{P})$ represents the population proportion (assumed to be 0.50 since this would provide the maximum sample size). (d) is the degree of accuracy expressed as proportion $(0.05)$ and $\left(\mathrm{X}^{2}\right)$ is the table value of chi-square for 1 degree of freedom at the desired confidence level (0.05).

\subsection{Measurement Instruments and Data Collection}

As mentioned previously, 345 sample questionnaires were distributed among the students during the May 2019 semester, and 309 of the collected copies were analyzed. In terms of online communication (OC) six items, motives to communicate (MC) six items, communication self-efficacy (CS)six items, and attitude towards use(AT) six itemswereadopted from[80]. In addition, measurements of students' satisfaction (SS) were performed using five items, all of which were derived from [8]. Finally, students' academic performance (AP) was measured using six suggested indicators from [13].

\section{RESULTS AND ANALYSIS}

The result of Cronbach's Alpha reliability coefficient was 0.912 of the (online communication, motives to communicate, communication self-efficacy, attitude towards use, students' satisfaction and academic performance). The evaluation of discriminant validity (DV) was conducted through the use of three criteria namely: index among variables which should be below 0.80 [78], the average variance extracted (AVE) value of each construct that needs to be equal to or above 0.50 , and square of (AVE) of each construct that has be above, in value, then the inter construct correlations (IC) connected with the factor [78]. Furthermore, crematory factor analysis (CFA) results with factor loading (FL) should be 0.70 or over while the results of Cronbach's Alpha (CA) are agreed to be $\geq 0.70$ [78]. The researchers also add that composite reliability (CR) should be $\geq 0.70$.

\subsection{Measurement Model and Instrumentation}

The beginning stage in the assertion of the legitimacy and dependability of the model is the use of the Partial Least Square. Basic Equations Modelling (PLS-SEM), Smart PLS 2.0. Preceding the theories were tried, two phases were used to affirm the fitness model's integrity. In like way, build legitimacy that spreads components loadings; composite unwavering quality, Cronbach's alpha, and merging legitimacy was determined. The recommendation gave by [81]in light of making use of the standard test to affirm discriminant legitimacy was used.

\subsection{Construct Validity of the Measurements}

Develop legitimacy is delineated as the level to which the things used to gauge a component can appropriately quantify the idea they were meant to quantify [78]. The entire things used to gauge the develops should stack essentially to their individual develops rather than different builds. This was guaranteed by leading an orderly audit of writing in the mission to deliver things that have as of now been set up and tried by earlier writers. On the premise of the component analysis, it was affirmed that things were reasonably named to them develops as they showed high loadings on them stood out from various develops (See Table 1).

Table 1: Factors Loading and Cross-Loading of items

\begin{tabular}{|c|c|c|c|c|c||c|c|}
\hline Factors & Items & AT & CS & MC & OC & AP & SS \\
\hline \multirow{4}{*}{ Attitude towards Use } & AT1 & 0.812513 & 0.492830 & 0.519101 & 0.495666 & 0.491474 & 0.539835 \\
\cline { 2 - 8 } & AT2 & 0.825838 & 0.442931 & 0.447509 & 0.457286 & 0.484788 & 0.538209 \\
\cline { 2 - 8 } & AT3 & 0.704489 & 0.415351 & 0.390799 & 0.449089 & 0.391030 & 0.467414 \\
\cline { 2 - 8 } & AT4 & 0.842891 & 0.441040 & 0.461312 & 0.496037 & 0.533168 & 0.570962 \\
\cline { 2 - 8 } & AT5 & 0.836441 & 0.451729 & 0.467675 & 0.517161 & 0.568067 & 0.617407 \\
\cline { 2 - 8 } & AT6 & 0.836360 & 0.484610 & 0.458842 & 0.529318 & 0.564676 & 0.619070 \\
\hline $\begin{array}{c}\text { Communication Self- } \\
\text { Efficacy }\end{array}$ & CS1 & 0.403391 & 0.736649 & 0.593420 & 0.414150 & 0.435770 & 0.426489 \\
\cline { 2 - 8 } & CS2 & 0.395107 & 0.784199 & 0.501284 & 0.361548 & 0.406560 & 0.414992 \\
\cline { 2 - 8 } & CS3 & 0.334277 & 0.746561 & 0.424206 & 0.309085 & 0.374887 & 0.335959 \\
\cline { 2 - 8 } & CS4 & 0.368044 & 0.773858 & 0.435127 & 0.327171 & 0.381762 & 0.360270 \\
\cline { 2 - 8 } & CS5 & 0.399912 & 0.779809 & 0.457948 & 0.354519 & 0.369049 & 0.388142 \\
\cline { 2 - 8 } & CS6 & 0.577935 & 0.755063 & 0.492433 & 0.554714 & 0.530089 & 0.541537 \\
\hline \hline
\end{tabular}


Qusay Al-Maatouk et al., International Journal of Advanced Trends in Computer Science and Engineering, 9(2), March - April 2020, 1505 - 1517

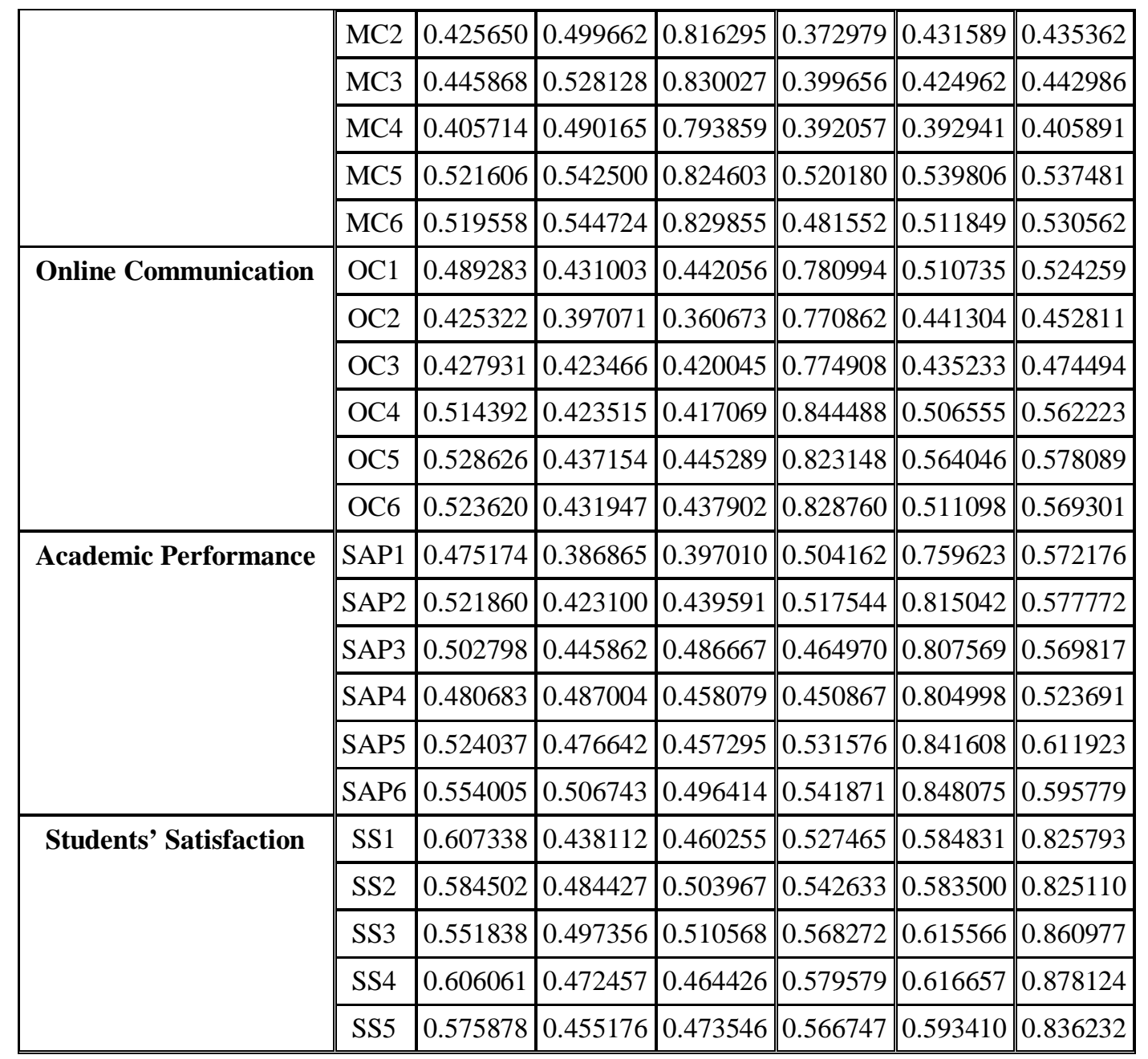

\subsection{Convergent Validity of the Measurements}

The composite reliability values differed from 0.926084 to 0.893047 and they are everywhere throughout the prescribed cut-off estimation of 0.70 , with Cronbach values contrasting from 0.900086 to 0.858377 , over the prescribed cut-off estimation of 0.60. In addition, the normal change removed
(AVE) values contrasted from 0.714882 to 0.582008 (all surpassed the cut-off estimation of 0.5), with critical element loadings surpassing 0.50 . These qualities all went over the prescribed an incentive by $[78,81]$. Table 2 presents the CFA results of the measurement model.

Table 2: Convergent Validity

\begin{tabular}{|c|c|c|c|c|c|c|}
\hline Factors & Items & $\begin{array}{c}\text { Factors } \\
\text { Loading }\end{array}$ & $\begin{array}{l}\text { Composite } \\
\text { Reliability }\end{array}$ & AVE & $\begin{array}{c}\text { Cronbach's } \\
\text { Alpha }\end{array}$ & R Square \\
\hline \multirow[t]{6}{*}{ Attitude towards Use } & AT1 & 0.812513 & \multirow{6}{*}{0.920026} & \multirow{6}{*}{0.658014} & \multirow{6}{*}{0.895314} & \multirow{6}{*}{0.477512} \\
\hline & AT2 & 0.825838 & & & & \\
\hline & AT3 & 0.704489 & & & & \\
\hline & AT4 & 0.842891 & & & & \\
\hline & AT5 & 0.836441 & & & & \\
\hline & AT6 & 0.836360 & & & & \\
\hline \multirow{4}{*}{$\begin{array}{c}\text { Communication Self- } \\
\text { Efficacy }\end{array}$} & $\mathrm{CS} 1$ & 0.736649 & \multirow{4}{*}{0.893047} & \multirow{4}{*}{0.582008} & \multirow{4}{*}{0.858377} & \multirow{4}{*}{0.000000} \\
\hline & $\mathrm{CS} 2$ & 0.784199 & & & & \\
\hline & CS3 & 0.746561 & & & & \\
\hline & CS4 & 0.773858 & & & & \\
\hline
\end{tabular}




\begin{tabular}{|c|c|c|c|c|c|c|}
\hline & CS5 & 0.779809 & & & & \\
\hline & CS6 & 0.755063 & & & & \\
\hline \multirow[t]{6}{*}{ Motives to Communicate } & MC1 & 0.789940 & \multirow{6}{*}{0.921878} & \multirow{6}{*}{0.663022} & \multirow{6}{*}{0.898734} & \multirow{6}{*}{0.000000} \\
\hline & MC2 & 0.816295 & & & & \\
\hline & MC3 & 0.830027 & & & & \\
\hline & MC4 & 0.793859 & & & & \\
\hline & MC5 & 0.824603 & & & & \\
\hline & MC6 & 0.829855 & & & & \\
\hline \multirow[t]{6}{*}{ Online Communication } & OC1 & 0.780994 & \multirow{6}{*}{0.916560} & \multirow{6}{*}{0.647040} & \multirow{6}{*}{0.890877} & \multirow{6}{*}{0.000000} \\
\hline & OC2 & 0.770862 & & & & \\
\hline & OC3 & 0.774908 & & & & \\
\hline & OC4 & 0.844488 & & & & \\
\hline & OC5 & 0.823148 & & & & \\
\hline & OC6 & 0.828760 & & & & \\
\hline \multirow[t]{6}{*}{ Academic Performance } & SAP1 & 0.759623 & \multirow{6}{*}{0.921327} & \multirow{6}{*}{0.661508} & \multirow{6}{*}{0.897337} & \multirow{6}{*}{0.537992} \\
\hline & SAP2 & 0.815042 & & & & \\
\hline & SAP3 & 0.807569 & & & & \\
\hline & SAP4 & 0.804998 & & & & \\
\hline & SAP5 & 0.841608 & & & & \\
\hline & SAP6 & 0.848075 & & & & \\
\hline \multirow[t]{5}{*}{ Students' Satisfaction } & SS1 & 0.825793 & \multirow{5}{*}{0.926084} & \multirow{5}{*}{0.714882} & \multirow{5}{*}{0.900086} & \multirow{5}{*}{0.479417} \\
\hline & SS2 & 0.825110 & & & & \\
\hline & SS3 & 0.860977 & & & & \\
\hline & SS4 & 0.878124 & & & & \\
\hline & SS5 & 0.836232 & & & & \\
\hline
\end{tabular}

\subsection{Discriminant Validity of Measures}

The level to which an idea and its pointers go astray from another idea and its markers is surveyed by discriminant legitimacy [82]. The AVE esteem is well over 0.50 and is critical at $\mathrm{p}=0.001$ and this shows that discriminant legitimacy is bolstered for the whole builds [81]. In such manner, [78]clarified that the relationships between things in two develop ought not to surpass the square base of the normal fluctuation shared by a solitary develops things (See Table 3).

Table 3: Latent Variable Correlations

\begin{tabular}{|l|c|c|c|c|c||c|}
\hline \multicolumn{1}{|c|}{ Factors } & AP & AU & CS & MC & OC & SS \\
\hline Academic Performance (AP) & 1.000000 & & & & & \\
\hline Attitude towards Use (AT) & 0.627773 & 1.000000 & & & & \\
\hline Communication Self-Efficacy (CS) & 0.558945 & 0.560948 & 1.000000 & & & \\
\hline Motives to Communicate (MC) & 0.560804 & 0.565046 & 0.638823 & 1.000000 & & \\
\hline Online Communication (OC) & 0.618398 & 0.606222 & 0.527101 & 0.523931 & 1.000000 & \\
\hline Students' Satisfaction (SS) & 0.708363 & 0.692400 & 0.555197 & 0.570442 & 0.658843 & 1.000000 \\
\hline
\end{tabular}


Qusay Al-Maatouk et al., International Journal of Advanced Trends in Computer Science and Engineering, 9(2), March - April 2020, 1505 - 1517

\subsection{Analysis of the Structural Model}

Taking after the assurance of the integrity of the demonstrated estimation, the following stride involved the testing of the conjectured connections among the builds. The specialist utilized the Smart-PLS 2.0 where the model was analysed by leading the PLS calculation. The way coefficients were then delivered as portrayed in Figure 2and Figure 3, show the theories on table 4.

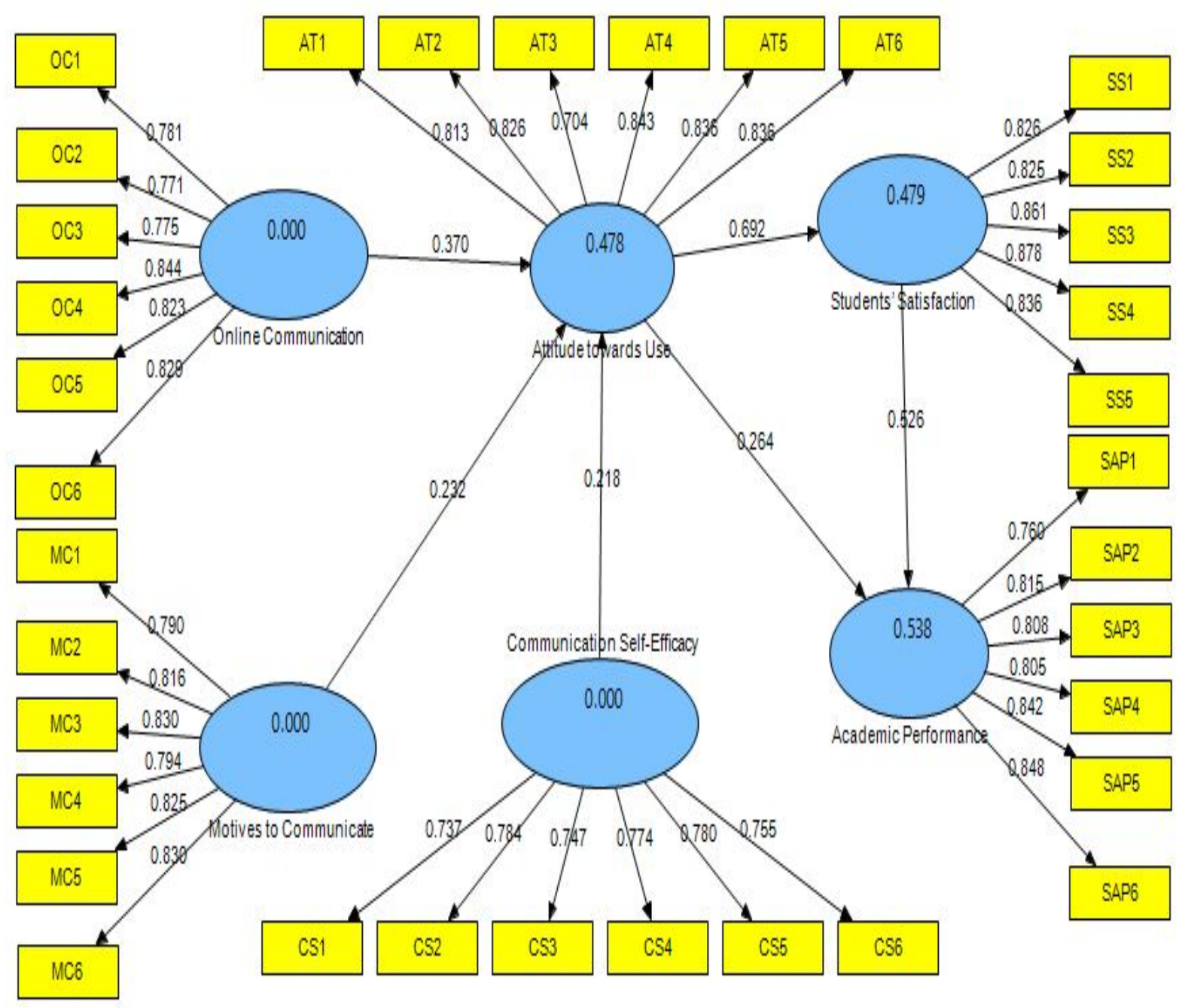

Figure 2: Path Coefficients Results 


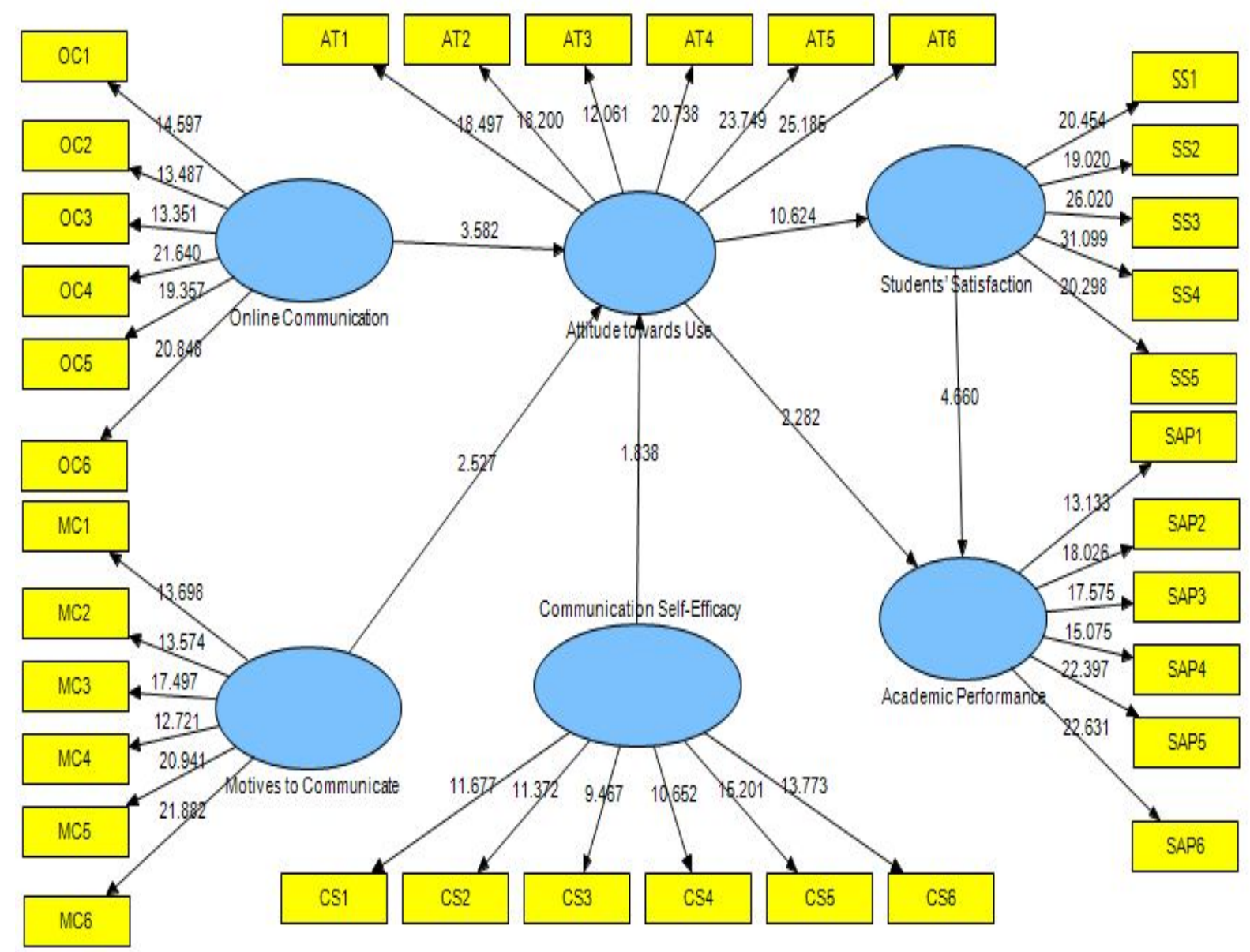

Figure 3: Path Coefficients T Values

Table 4: Hypotheses testing

\begin{tabular}{|c|c|c|c|c|c|c|c|}
\hline $\mathrm{H}$ & Independent & Relationship & Dependent & $\begin{array}{c}\text { Path } \\
\text { Coefficient }\end{array}$ & $\begin{array}{c}\text { Standard } \\
. \mathrm{E}\end{array}$ & $\mathrm{T}$. Value & Result \\
\hline 1 & $\mathrm{OC}$ & $\longrightarrow$ & $\mathrm{AT}$ & 0.369815 & 0.103239 & 3.582111 & Supported \\
\hline 2 & $\mathrm{MC}$ & $\longrightarrow$ & $\mathrm{AT}$ & 0.232246 & 0.091897 & 2.527230 & Supported \\
\hline 3 & $\mathrm{CS}$ & $\longrightarrow$ & $\mathrm{AT}$ & 0.217654 & 0.118442 & 1.837634 & Supported \\
\hline 4 & $\mathrm{AT}$ & $\longrightarrow$ & $\mathrm{SS}$ & 0.692400 & 0.065175 & 10.623688 & Supported \\
\hline 5 & $\mathrm{AT}$ & $\longrightarrow$ & $\mathrm{AP}$ & 0.263748 & 0.115593 & 2.281692 & Supported \\
\hline 6 & $\mathrm{SS}$ & $\longrightarrow$ & $\mathrm{AP}$ & 0.525744 & 0.112822 & 4.659944 & Supported \\
\hline
\end{tabular}

Regarding the first hypothesis, the relationship between online communication and attitude towards use $(\beta=0.369815, \mathrm{t}=3.582111)$. Thus, H1 was supported. The second hypothesis is positive relationship as the analysis between motives to communicate and attitude towards use $(\beta=0.232246, t=2.527230)$. Thus, $\mathrm{H} 2$ was supported. Next hypothesis number three the relationship between communication self-efficacy and attitude towards use $(\beta=0.217654, \quad \mathrm{t}=1.837634)$. Thus, $\mathrm{H} 3$ was supported. Similarly, the relationship between attitude towards use and students' satisfaction $(\beta=0.692400, t=10.623688)$. Thus, $\mathrm{H} 4$ was supported. And the fifth hypothesis the relationship between attitude towards use and academic performance ( $\beta=0.263748, t=2.281692)$. Thus, H5 was supported. Finally, hypothesis number six the relationship between students' satisfaction and academic performance $(\beta=0.525744$, $\mathrm{t}=4$.659944). Thus, H6 was supported.

\section{DISCUSSION AND IMPLEMENTATIONS}

The goal of this study was to analyse the effect of students' communication via various social media platforms on the academic performance of university students. the study contributes to the body of knowledge with empirical evidence of the direct effect on educational performance for university students. The support for all the hypotheses proved that communicating via social networking sites has an adverse effect on students' academic performance. This research contributes to present IS theory in a number of ways by extending the contributions of Shannon and weaver (1949) through combining their theory and incorporating further variables to study the effects of Online 
communication, motives to communicate and communication self-efficacy as the most influencing factors on social media effects on SAP and developed the artefact of this study with significant correlations among the supported hypotheses has been achieved accordingly. Diversity of aspects affecting interactivity has been proven by previous studies in multiple research fields associated to social media usage. These factors are based on communication theory and shows significant correlation among the supported hypotheses.Despite much literature on the negative consequences of the usage of communication related technologies, the effect of communication and attitude towards usage of social media platforms on AP received very little attention in the literature. In addition, while scholars have tended to focus on either the positive or negative issues of social media platforms addiction in the present research, we have attempted to understand the processes involved, that is, how communication affects the attitude towards use and the strong positive impact on students' academic performance in university level. The outcomes of the present research are indicating some of potential managerial implications. Recent studies discovered the evaluation of the students' performance based on Internet of Things [83-85] which subsequently related to communication devices usage and social media applications usage. This indicates the possibility of high volume of communication technologies usage among university students. This suggests that higher education authority or managers may consider various facilities and activities to ensure positive attitude towards use of social media platforms for educational purposes within the campus. For example, free academic journals membership, unlimited access, different learning platform access developed by the university and so on. The result of the study also underpins that academic leaders such as head of schools and faculty deans can choose the best candidates for their institution for further in-depth study.

\subsection{Conclusion and Future Work}

The study shed lights on the factors of SS and SAP related to the utilization of social media for the purposes of learning and communication among university students from an integrated perspective based on communication theory. The outcomes of this research suggest that if students have greater online communication, motives to communication, communication self-efficacy, attitude towards use, which in turn increase SS and SAP. Thus, the outcomes demonstrated the factors with greatest influence on the utilization of social media platforms for the purposes related to learning and communication, which in turn affect SS and SAP. The model developed by this research is recommended be employed as a supportive tool for investigation the utilization of social media platforms for learning and communication purposes to enhance students' satisfaction and academic performance other higher education institutes.This study was limited only to influential factors of attitude towards use of social media for communication and learning. However, there are other various factors which could lead to investigate. Thus, further exploration should also assess the students' intention to continue or discontinue using social media for communication and learning to gain a better understanding of discontinuous and continuous usage intention.Based on geographical limitation, this study gathered data only from respondents in Malaysia. Thus, cross-cultural research in broader geographical sample distribution regarding the utilization of social media platforms for communication and learning might provide findings in more depth for future research. The data collected for this study was constrained to two universities in Malaysia. Further studies are recommended to which collect data from a larger number of students from multi-institutions in order to enhance and generalize the findings.

\section{REFERENCES}

1. Lim WM: Social media in medical and health care: opportunities and challenges. Marketing intelligence \& planning 2016, 34(7):964-976. https://doi.org/10.1108/MIP-06-2015-0120

2. Ryu D, Jeong J: Two Faces of Today's Learners: Multiple Identity Formation. Journal of Educational Computing Research 2019, 57(6):1351-1375. https://doi.org/10.1177/0735633118791830

3. Fan W, Gordon MD: The power of social media analytics. Commun Acm 2014, 57(6):74-81.

4. Stats IL: Internet users by country. 2016.

5. Nordin N, Wahab RA, Dahlan NA: Approaches to learning among trainee teachers: Malaysian experiences. Procedia-Social and Behavioral Sciences 2013, 105:284-293.

https://doi.org/10.1016/j.sbspro.2013.11.030

6. Ferrara E, Yang Z: Measuring emotional contagion in social media. PloS one 2015, 10(11):e0142390.

7. Schweinsberg S, Heizmann H, Darcy S, Wearing S, Djolic M: Establishing academic leadership praxis in sustainable tourism: lessons from the past and bridges to the future. Journal of Sustainable Tourism 2018, 26(9):1577-1586.

8. Al-Rahmi WM, Othman MS, Yusuf LM: Exploring the factors that affect student satisfaction through using e-learning in Malaysian higher education institutions. Mediterranean Journal of Social Sciences 2015, 6(4):299.

9. Castillo G, Haddud A: Social Media Usage in Higher Education in Online Business Programs. In: On the Line. Springer; 2018: 203-218.

10. Al-Rahmi WM, Yahaya N, Aldraiweesh AA, Alamri MM, Aljarboa NA, Alturki U, Aljeraiwi AA: Integrating technology acceptance model with innovation diffusion theory: An empirical investigation on students' intention to use Elearning systems. IEEE Access 2019, 7:2679726809.

11. Ouhrir S, Lotfi S, Talbi M: Students' Views on Elearning and Knowledge of Learning Platforms: Case of a Professional License at the Higher Normal School of Casablanca. International 
Journal of Advanced Trends in Computer Science and Engineering 2019, 8(5):2282-2288. https://doi.org/10.30534/ijatcse/2019/66852019

12. Taylor EW: Transformative learning theory. In: Transformative learning meets bildung. Brill Sense; 2017: 17-29.

13. Buzzetto-Hollywood N, Quinn K, Wang W, Hill A: Grit in online education. Journal of Education, Society and Behavioural Science 2019:1-11.

14. Al-rahmi WM, Othman MS, Yusuf LM: Using social media for research: The role of interactivity, collaborative learning, and engagement on the performance of students in Malaysian post-secondary institutes. Mediterranean Journal of Social Sciences 2015, 6(5):536.

15. Buzzetto-More NA, Johnson R, Elobaid M: Communicating and sharing in the semantic web: An examination of social media risks, consequences, and attitudinal awareness. Interdisciplinary Journal of e-Skills and Life Long Learning 2015, 11:47-66.

16. Schiavi GS, da Silva Momo F, Behr A, Scornavacca E: Understanding Smartphones Usage Context in the Classroom. 2019.

17. McCay-Peet L, Quan-Haase A: What is social media and what questions can social media research help us answer. The SAGE handbook of social media research methods 2017:13-26. https://doi.org/10.4135/9781473983847.n2

18. Al-Rahmi WM, Othman MS, Yusuf LM: Effect of engagement and collaborative learning on satisfaction through the use of social media on Malaysian higher education. Res J Appl Sci, Eng Technol 2015, 9(12):1132-1142.

19. Alwagait E, Shahzad B, Alim S: Impact of social media usage on students academic performance in Saudi Arabia. Computers in Human Behavior 2015, 51:1092-1097.

20. Vanden Abeele MM, Antheunis ML, Pollmann MM, Schouten AP, Liebrecht CC, Van Der Wijst PJ, Van Amelsvoort MA, Bartels J, Krahmer EJ, Maes FA: Does Facebook Use Predict College Students' Social Capital? A Replication of Ellison, Steinfield, and Lampe's (2007) Study Using the Original and More Recent Measures of Facebook Use and Social Capital. Communication Studies 2018, 69(3):272-282.

21. Al-Rahmi W, Aldraiweesh A, Yahaya N, Kamin YB, Zeki AM: Massive open online courses (MOOCs): Data on higher education. Data in brief 2019, 22:118-125.

https://doi.org/10.1016/j.dib.2018.11.139

22. Dolan R, Conduit J, Frethey-Bentham C, Fahy J, Goodman S: Social media engagement behavior: A framework for engaging customers through social media content. European Journal of Marketing 2019.

23. Amador PV, Amador JM: Academic Help Seeking: a Framework for Conceptualizing
Facebook Use for Higher Education Support. TechTrends 2017, 61(2):195-202. https://doi.org/10.1007/s11528-016-0135-3

24. Hamid S, Bukhari S, Ravana SD, Norman AA, Ijab MT: Role of social media in information-seeking behaviour of international students: A systematic literature review. Aslib Journal of Information Management 2016, 68(5):643-666.

25. Rezaei DF, Ritter NL: Social Media in Education: Gains in Student Learning and Instructor Best Practices. In: Social Media in Education: Breakthroughs in Research and Practice. IGI Global; 2018: 12-33.

26. Josefsson P, Hrastinski S, Pargman D, Pargman TC: The student, the private and the professional role: Students' social media use. Education and Information Technologies 2016, 21(6):1583-1594. https://doi.org/10.1007/s10639-015-9403-7

27. Livingston JC: Using Technology with the Next Generation Science Standards: A Semester Curriculum for $\mathbf{7 t h} / \mathbf{8 t h}$ Grade. Martin Luther College; 2017.

28. Walden JA: Integrating social media into the workplace: A study of shifting technology use repertoires. Journal of Broadcasting \& Electronic Media 2016, 60(2):347-363.

29. Ledbetter AM, Finn AN: Why do students use mobile technology for social purposes during Class? Modeling teacher credibility, learner empowerment, and online communication attitude as predictors. Communication Education 2016, 65(1):1-23.

30. Denker KJ, Manning J, Heuett KB, Summers ME: Twitter in the classroom: Modeling online communication attitudes and student motivations to connect. Computers in Human Behavior 2018, 79:1-8.

31. Tang A, Lahat A, Crowley MJ, Wu J, Schmidt LA: Neurodevelopmental differences to social exclusion: An event-related neural oscillation study of children, adolescents, and adults. Emotion 2019, 19(3):520.

32. Tatum NT, Martin JC, Kemper B: Chronemics in Instructor-Student E-Mail Communication: An Experimental Examination of Student Evaluations of Instructor Response Speeds. Communication Research Reports 2018, 35(1):3341.

33. Burns EC, Martin AJ, Collie RJ: Understanding the role of adaptability and personal best $(\mathrm{PB})$ goals in students' academic outcomes: A social cognitive perspective. BJEP Monograph Series II 2017, 12:111-143.

34. Khan GF: Social media for government: a practical guide to understanding, implementing, and managing social media tools in the public sphere: Springer; 2017.

https://doi.org/10.1007/978-981-10-2942-4_7

35. Myers SA: A longitudinal analysis of students' motives for communicating with their 
instructors. Communication Education 2017, 66(4):467-473.

36. Bolkan S, Goodboy AK, Myers SA: Conditional processes of effective instructor communication and increases in students' cognitive learning. Communication Education 2017, 66(2):129-147.

37. Chugh $\mathrm{R}$, Ruhi $\mathrm{U}$ : Social media in higher education: A literature review of Facebook. Education and Information Technologies 2018, 23(2):605-616.

38. Bahati B: Extending student discussions beyond lecture room walls via Facebook. Journal of Education and Practice 2015, 6(15):160-171.

39. Northey G, Bucic T, Chylinski M, Govind R: Increasing student engagement using asynchronous learning. Journal of Marketing Education 2015, 37(3):171-180.

https://doi.org/10.1177/0273475315589814

40. Ko S, Rossen S: Teaching online: A practical guide: Routledge; 2017.

41. Bensadda $\mathrm{H}$ : Using code-switching as a factor to foster teachers' role in EFL classes. The case of Master one teachers at Mohamed Khider University. 2019.

42. Martin AJ, Ginns P, Papworth B: Motivation and engagement: Same or different? Does it matter?Learning and Individual Differences 2017, 55:150-162.

43. Forkosh-Baruch A, Hershkovitz A: Knowing Me, Knowing You: Teachers' Perceptions of Communication with their Students on Facebook. Interdisciplinary Journal of e-Skills and Lifelong Learning 2019, 15:59-81.

https://doi.org/10.28945/4256

44. Vohs KD, Baumeister RF: Handbook of selfregulation: Research, theory, and applications: Guilford Publications; 2016.

45. Sarac A, Aslan-Tutak F: The Relationship between Teacher Efficacy, and Students' Trigonometry Self-Efficacy and Achievement. International Journal for Mathematics Teaching \& Learning 2017, 18(1).

46. Kim H, Lee J, Oh SE: Individual characteristics influencing the sharing of knowledge on social networking services: online identity, selfefficacy, and knowledge sharing intentions. Behaviour \& Information Technology 2019:1-12.

47. Strich F, Mayer A-S, Fiedler M: A Social Network Approach to Blogs: Improving Digital Collaborative Learning. 2019.

48. Imran MK, Iqbal SMJ, Aslam U, Fatima T: Does social media promote knowledge exchange? A qualitative insight. Management Decision 2019, 57(3):688-702.

49. Chhim PP, Somers TM, Chinnam RB: Knowledge reuse through electronic knowledge repositories: a multi theoretical study. Journal of Knowledge Management 2017, 21(4):741-764.
50. Pee LG: Community's knowledge need and knowledge sharing in Wikipedia. Journal of Knowledge Management 2018, 22(4):912-930.

51. Dwivedi YK, Rana NP, Jeyaraj A, Clement M, Williams MD: Re-examining the unified theory of acceptance and use of technology (UTAUT): Towards a revised theoretical model. Information Systems Frontiers 2019, 21(3):719-734. https://doi.org/10.1007/s10796-017-9774-y

52. Lowe $\mathrm{R}$, Norman $\mathrm{P}$ : Information processing in illness representation: Implications from an associative-learning framework. Health Psychology 2017, 36(3):280.

53. Becton JB, Walker HJ, Schwager P, Gilstrap JB: Is what you see what you get? Investigating the relationship between social media content and counterproductive work behaviors, alcohol consumption, and episodic heavy drinking. The International Journal of Human Resource Management 2019, 30(15):2251-2272.

54. Cheung $C$, Yin W: ASSESSING NETWORK MEDIA LITERACY IN CHINA: THE DEVELOPMENT AND VALIDATION OF A COMPREHENSIVE ASSESSMENT INSTRUMENT. International Journal of Media and Information Literacy 2018, 3(2).

https://doi.org/10.13187/ijmil.2018.2.53

55. Anderberg P, Eivazzadeh S, Berglund JS: A Novel Instrument for Measuring Older People's Attitudes Toward Technology (TechPH): Development and Validation. Journal of medical Internet research 2019, 21(5): 13951.

56. Xiao L: Analyzing consumer online group buying motivations: An interpretive structural modeling approach. Telematics and Informatics 2018, 35(4):629-642.

57. Anni CT: School Counselors' Intention to Use Technology: The Technology Acceptance Model. Turkish Online Journal of Educational TechnologyTOJET 2018, 17(2):120-124.

58. Al-Rahmi WM, Yahaya N, Alamri MM, Aljarboa NA, Kamin YB, Saud MSB: How cyber stalking and cyber bullying affect students' open learning. IEEE Access 2019, 7:20199-20210.

59. Tatone J, Gallicano TD, Tefertiller A: I love tweeting in class, but...: A qualitative study of student perceptions of the impact of Twitter in large lecture classes. Journal of Public Relations Education 2017, 3(1):1-13.

60. González MR, Gasco J, Llopis J: Facebook and academic performance: A positive outcome. The Anthropologist 2016, 23(1-2):59-67.

61. Joo YJ, Park S, Shin EK: Students' expectation, satisfaction, and continuance intention to use digital textbooks. Computers in Human Behavior 2017, 69:83-90.

https://doi.org/10.1016/j.chb.2016.12.025

62. Al-Rahmi WM, Yahaya N, Aldraiweesh AA, Alturki U, Alamri MM, Saud MSB, Kamin YB, Aljeraiwi AA, Alhamed OA: Big data adoption 
and knowledge management sharing: An empirical investigation on their adoption and sustainability as a purpose of education. IEEE Access 2019, 7:47245-47258.

63. Abuhassna H, Zakaria MAZM, Yahya N, Mohd Kosnin A, Al-Rahmi WM: Examining Students' Satisfaction and Learning Autonomy through Web-Based Courses. International Journal of Advanced Trends in Computer Science and Engineering 2020, 9(9):356-370.

https://doi.org/10.30534/ijatcse/2020/53912020

64. Kern R, Ware P, Warschauer M: Computermediated communication and language learning. In: The Routledge Handbook of English Language Teaching. Routledge; 2016: 560-573.

65. Alalwan N, Al-Rahmi WM, Alfarraj O, Alzahrani A, Yahaya N, Al-Rahmi AM: Integrated Three Theories to Develop a Model of Factors Affecting Students' Academic Performance in Higher Education. IEEE Access 2019, 7:9872598742.

66. Rahman NSA, Handayani L, Othman MS, AlRahmi WM, Kasim S, Sutikno T: Social media for collaborative learning. International Journal of Electrical \& Computer Engineering (2088-8708) 2020, 10.

67. Labib NM, Sabry AE, Mostafa RH, Morcos EW: Use of Social Networks Sites (SNSs) as A Collaborative Learning Technique: Survey Analysis and Mining Approach. In: Proceedings of the International Conference on Data Mining (DMIN): 2015: The Steering Committee of The World Congress in Computer Science, Computer ...; 2015: 44.

68. Alkhathlan AA, Al-Daraiseh AA: An analytical study of the use of social networks for collaborative learning in higher education. International Journal of Modern Education and Computer Science 2017, 9(2):1.

https://doi.org/10.5815/ijmecs.2017.02.01

69. Goh C, Leong C, Kasmin K, Hii P, Tan O: Students' experiences, learning outcomes and satisfaction in e-learning. Journal of E-learning and Knowledge Society 2017, 13(2).

70. Saha N, Karpinski AC: The influence of social media on international students' global life satisfaction and academic performance. In: Campus support services, programs, and policies for international students. IGI Global; 2016: 57-76.

71. Tartari E, Tartari A, Beshiri D: The Involvement of Students in Social Network Sites Affects Their Learning. International Journal of Emerging Technologies in Learning (iJET) 2019, 14(13):33-46.

72. Laha D, Pal R: Does internet change the concept of education: An institute based cross sectional study to reveal the opinion of the students about classroom teaching and internet as an education. 2018.

73. Karpinski AC, D'Agostino JV, Williams A-EK, Highland SA, Mellott JA: The Relationship
Between Online Formative Assessment and State Test Scores Using Multilevel Modeling. In: Advanced Methodologies and Technologies in Modern Education Delivery. IGI Global; 2019: 767-778.

74. Al-Qaysi N, Mohamad-Nordin N, Al-Emran M, AlSharafi MA: Understanding the differences in students' attitudes towards social media use: A case study from Oman. In: 2019 IEEE Student Conference on Research and Development (SCOReD): 2019: IEEE; 2019: 176-179.

75. Cooke S: Social teaching: Student perspectives on the inclusion of social media in higher education. Education and Information Technologies 2017, 22(1):255-269. https://doi.org/10.1007/s10639-015-9444-y

76. Liu D, Kirschner PA, Karpinski AC: A metaanalysis of the relationship of academic performance and Social Network Site use among adolescents and young adults. Computers in Human Behavior 2017, 77:148-157.

77. Mathur G, Nathani N, Sharma A, Modi D, Arora G: Impact of Facebook Usage On Students' Involvement in Studies. Available at SSRN 33237842019.

78. Hair J, Hollingsworth CL, Randolph AB, Chong AYL: An updated and expanded assessment of PLS-SEM in information systems research. Industrial Management \& Data Systems 2017.

79. Krejcie RV, Morgan DW: Determining sample size for research activities. Educational and psychological measurement 1970, 30(3):607-610.

80. Weng F, Yang R-J, Ho H-J, Su H-M: A TAMbased study of the attitude towards use intention of multimedia among school teachers. Applied System Innovation 2018, 1(3):36.

https://doi.org/10.3390/asi1030036

81. Fornell C, Larcker DF: Evaluating structural equation models with unobservable variables and measurement error. Journal of marketing research 1981, 18(1):39-50.

82. Bagozzi RP, Yi Y, Nassen KD: Representation of measurement error in marketing variables: Review of approaches and extension to threefacet designs. Journal of Econometrics 1998, 89(12):393-421.

83. Verma P, Sood SK, Kalra S: Smart computing based student performance evaluation framework for engineering education. Computer Applications in Engineering Education 2017, 25(6):977-991.

84. Díaz P, Ioannou A, Bhagat KK, Spector JM: Learning in a Digital World: Perspective on Interactive Technologies for Formal and Informal Education: Springer; 2019.

85. Iqbal MM, Farhan M, Jabbar S, Saleem Y, Khalid S: Multimedia based IoT-centric smart framework for eLearning paradigm. Multimedia Tools and Applications 2019, 78(3):3087-3106. 